\title{
Designing appropriate English learning materials for Nautical Department at Politeknik Ilmu Pelayaran (PIP) Semarang
}

\author{
Fatimah ${ }^{1}$, Irma Shinta Dewi ${ }^{2}$, Sri Purwantini ${ }^{3}$ \\ 1,3Politeknik Ilmu Pelayaran Semarang, 2Universitas Negeri Semarang
}

Received:

17-06-2020

Final revision:

12-08-2020

Published:

20-08-2020

Corresponding

author:

Fatimah

ftmh_c@yahoo.com

\begin{abstract}
This research is aimed to find out the target and learning needs of Nautical students at PIP Semarang and designing the appropriate material for nautical students at PIP Semarang. This is a research and development $(\mathrm{RnD})$ project. The steps of doing this research are (1) need analysis (2) make syllabus (3) designing materials (4) expert consultation (5) try out material, and (6) evaluation. The subject of this research is the third-semester students of Nautical Department at PIP Semarang. The instruments used are questionnaires for need analysis, interview guide and observation sheets. The data were analyzed by using descriptive quantitative and qualitative. The results of the research recommend three units namely (1) Initial Call (2) Message Marker and (3) On Board Communication Phrases which are developed with communicative approach. The research gives contribution to the teaching and learning English at Nautical Department of Politeknik Ilmu Pelayaran Semarang.
\end{abstract}

Keywords: designing material, English learning, Nautical Department

\section{Introduction}

The discussion of English for Specific Purposes or ESP tends to improve due to the rise of many new industries. ESP plays significant role since it prepares material for the target learners to be able to use appropriate and correct English for many purposes contexts of learners' possible future.

ESP itself comes with the huge challenges in the application. The students need to master General English or GE first before beginning ESP course (Guest, 2016). It will be difficult since in EFL countries such as Indonesia, the students' level are mostly in basic although they are in higher education. When first time having the kind of subject, most students feel surprised moreover get difficult. The difficulty comes since ESP is different with GE that they have studied before. The difference of ESP with GE lies on the prominence of content and unfamiliarity content to many teachers and students (Aniroh, 2019).

Although there are challenges and barriers, ESP comes to be more exciting to develop. There are some factors contributing the success of a learner in English for Specific Purposes Courses including social setting, the implementation of curriculum, affective factors, and mastery of metacognitive skill (Bernauss, 2008). The characteristics of students lies as important aspect. The adult learners in higher education such as at Politeknik Ilmu Pelayaran Semarang has unique characteristics and it effects on the learning strategies. As Hashim (2018) describes the learning strategies used by adult learners of TESL. It is said that the strategies fits to them is the active ones and should be communicative in speaking.

English for Specific Purposes is an approach of language teaching in which all decisions as to context and methods are based on the learner's reason for learning (Hutchison, Waters, Alan, 1989: 19). There are some studies that focus on designing material. Among those studies are the one conducted by Cheng-jun (2006) who designed communicative task for college English courses. It focused on the medical academy in China. The result shows that communicative task is effective in teaching a foreign language in promoting the learners' competence in using the language to do things they need to do. As stated by Masuram, (2019), since speaking skill tends to be more difficult than the other skill, there need more study focus on this. There is usually a gap between the prescribed textbook and present 
competence of the students was found by the research. Therefore, the material that really meet the learners need should be developed by the lecturer.

In the economic study, there is also study in designing the material that appropriate for the students ( Yahya:2016). It is found that applying ESP had positive perspectives toward teaching and learning process. Another study in ESP scope is written by Attan (2016). The result is engaging workplace specialist in determining the oral ability construct of the graduating students is possible, in fact highly recommended. In maritime education, there are some studies related to analysing the learners and target needs. The studies conducted by Dirgeyasa (2018), Aeni et al (2018), and Ahmmed et al (2020) found that speaking skill is the most important skill over the three skills in maritime higher education.

International Maritime Organisation (IMO) has stated that English become the international language in communication at sea. It makes English mastery becomes a compulsory need for seafarers. English used for communication at sea or known as Maritime English is global language used in the communication between ships and shore, among the crew members on board and between the crews and passengers during sailing on the sea (Demydencko, 2012). The policy hopes to decrease the number of incidents happen on the sea especially because of the communication problem. The need for seafarers in South Asia is increasing in last several year (Marselia, 2017). As one of the South East Asia Countries, Indonesia was challenged to prepare maritime students to fulfill the requirements. In doing so, maritime educational institutions in Indonesia should equip the students with good proficiency of English.

The duty to train and educate the students to become qualified seafarer lies on the maritime education and training institution. One of them is Politeknik Ilmu Pelayaran (PIP) Semarang. It is one of a state maritime higher educations administered by ministry of transportation of Republic of Indonesia. Students of PIP Semarang is required to be able to communicate in English. The need is bigger since they are going to work in the industry that has multinational crews. In reality, there are still many students who have low skill in English. The available material for students of Politeknik Ilmu Pelayaran Semarang are still limited. Furthermore, the materials which are available in General English and tends to grammar-oriented.

Maritime English that belongs to English for Specific Purposes is something new for stu- dents. There are limited learning material to study. If it exists, it is not suitable for the students in Indonesia. Therefore considering the need of English mastery for the students and the lack of material available the paper aims to describe the learner's need that can also meet with the target group. Moreover, it also serves with the materials that specifically meet with the learners' need.

The research aimed to answer two research questions : what is the learning and target needs of Nautical Students and how is the process of designing material for the Nautical Students at Politeknik Ilmu Pelayaran Semarang.

\section{Method}

In developing the model of material for teaching the Maritime English, research and development approach by Borg and Gall was used. The major purpose of research and development was not to formulate or to test, but to develop a product for its use in classroom. Gay (1981:1) stated that research and development was not only to make or test a theory but also to develop the effective products that could be used in teaching and learning activity. The research and development by Borg and Gall (1989: 783-795) was conducted in ten steps, however this research limited into six steps six steps; research and information collecting, planning, developing, validating by experts, revising, and trying out of product. This research was a research and development project.

\section{Participants}

The sources of data were the English lecturers and the third semester students of Nautical E Class in Politeknik Ilmu Pelayaran Semarang with 24 students in number. A number of experts were asked to evaluate the material from the instructional and technical point of view. The material was validated by three lecturers who are the experts in material development. It was intended to obtain their appraisals toward the material developed

\section{Procedure}

First, the preliminary survey was conducted in the teaching and learning process. Based on the need analysis, planning the materials was conducted. It is followed by designing the materials. The materials were then validated by experts. They were validated by three lecturers who are experts in material development. After that the materials were revised. The last step was trying out the material. 


\section{Data Collection}

In the research, data can be taken either from documents or from people (Bardach, 2009). In this research, the data were collected by using instruments which covered questionnaires, interview guide and observation sheets. The data of the need analysis and target needs were collected by using observations and interviews. Meanwhile the data about the quality of the materials were collected by using questionnaires, observation and interviews.

\section{Data Analysis}

The data was analyzed quantitatively and qualitatively. The data about the students' learning and target needs were analyzed descriptively. The results were the description of the students' need in Maritime English class. The data of the interview were used to strengthen the need analysis. It was analyzed by conducting, recording and then transcribing. The yes-no questionnaires were analyzed quantitatively. It was used to get the students' perception toward the materials.

\section{Finding and Discussion}

The final product of this development was English materials for Nautical students at Politeknik Ilmu Pelayaran Semarang. The first step was by analyzing the learning and target needs of students. The result of need analysis showed that the target needs of students at Nautical department of Politeknik Ilmu Pelayaran Semarang in learning is to be able to communicate in English especially in operating the vessel at sea. Moreover, in the content of language skills, they need vocabulary exposure to increase all the main skills in English. Then, for listening, they need to learn more on pronunciation.

The analysis was conducted to find out the existing material available. To gain the information about the existing material in the classroom, the researchers conducted the observation, interviews and collected some documents used in the teaching such as curriculum, lesson plan and the books. From the analysis, it found that the material was not only very limited, but also not appropriate with the objective of the speaking and learning process, to make students active in communicating and practicing the speaking skill. It was more to be grammar oriented.

The need analysis was to get the initial data of the students, the lecturers and the teaching and learning process in the classroom. The result showed that the students in the class have good interest in learning Maritime English and think that it is interesting. However, they feel difficult in practicing it. Speaking was considered difficult for the students compared to other skills. It resulted to the non-activeness in the classroom. Similar with the condition, the lecturers also felt difficult in exploring the materials since it is very limited.

The second step was developing the product. The planning covered concept of product such as materials, feasibility of product in English teaching and learning process, exercises related to the materials, and assesment used for measuring mastery of the topic. As a result, the concept of the product was the integration between the material in Maritime English that belongs to English for Specific Purposes and the students' need. Standard Marine Communication Phrases (SMCP) was chosen since it is one that essential, moreover, there is limited material available related to this subject. The materials were developed based on International Maritime Organization (IMO) Model Course 3.17, the curriculum used by all the maritime academy in the countries that ratified IMO.

The materials have the characteristics of communicative task that aimed to have students communicate effectively and in manner appropriate to the context they are working in. Related with SMCP, the task can pursue the students not only accurately but also fluently communicate with other ships, port control even on board communication with the crews.

There were three experts in material development and also became as the validators in this research. The validations covered the content, vocabulary and structure, exercise, suitability to curriculum, suitability to the students, and suitability to lecturers. Based on the validation form given to them, it was concluded that the material was good enough. However, there were still some critics and suggestions. The experts suggested some aspects such as layout, instruction, colour and activities. The suggestions were followed up with the revisions. As the input from the experts were gathered, some improvement were made. Then, the implementation of limited tried out ran very well. The students enjoy and can understand the materials, getting some new phrases related to communication at sea and also practicing the communication in nearly-real setting.

The result of the research recommend 3 units namely: (1) Initial Call (2) Message Marker (3) On board Communication Phrases. The materials were developed with communicative approach. The first part of the books was starter. In 
Leksika Vol. 14, No.2, August 2020 : $67-72$

this part, it present a dialogue related to the topic. The dialogue was used to direct students to the next part of the unit. The next was study it. In this part, there was a set of theory about the topic based on the curriculum. The students should pay attention and study about the theory. then It was followed by listening part. The students are given activity to listen some phrases or sentences based on the theory they have studied. The activity was used to make students become familiar with the authentic phrases or sentences. Next part was about writing and speaking. There were some activities related to writing documents about the topic. In speaking part, students should make a role play based on the scenario.
The influence of the materials can be concluded from data got by doing the obsevation, interview and questionnaire. The observations were conducted both before the research, in the preliminary research and during the try out. There were some changes in the students' behavior in the class. The changes included their activeness, involvement, and happiness in the classroom. In order to measure the students' development, the researcher gave the ranges of scales.

Yahya, et.al (2018) that conduct research

Table 1. Analysis of Observation

\begin{tabular}{|c|c|c|c|c|c|}
\hline \multirow[t]{2}{*}{ No } & \multirow[t]{2}{*}{ Activities } & \multicolumn{2}{|c|}{ Meetings } & \multirow[t]{2}{*}{ Average } & \multirow[t]{2}{*}{ Scale } \\
\hline & & 1st & 2nd & & \\
\hline 1. & Attendance & 4 & 5 & 4.5 & Excellent \\
\hline 2. & Enjoyment in learning process & 4 & 4 & 4 & Very good \\
\hline 3. & Eagerness to do all activities & 5 & 4 & 4.5 & Excellent \\
\hline 4. & Learner activeness in learning process & 3 & 3 & 3 & Good \\
\hline 5. & Understanding the materials & 4 & 4 & 4 & Very good \\
\hline
\end{tabular}

The questionnaires were distributed to the lecturers and students. This research also attempted to obtain the users' perception toward the material being developed. The questions were about the usefulness of material to learn, the understandable content, the practicability, and the interest of the book. The data analysis was as follows :

Table 2. Analysis of Questionnaires

\begin{tabular}{|c|l|c|c|}
\hline No & Content of the questionnaire & Yes & No \\
\hline 1 & Usefullness to learn & 24 & - \\
\hline 2 & Understanding & 21 & 3 \\
\hline 3 & Practicability & 21 & 3 \\
\hline 4 & Interest & 23 & 1 \\
\hline
\end{tabular}

There were also open-ended questions in the questionnaires. Moreover, the students said that the communication part and VHF communication were their favorite part of the materials. There were some suggestions given by the students that they wrote in the questionnaires such as completing with images and pictures so that they can be more interesting, giving more activities that focus on listening and making the materials more simple so that they can understand them more easily.

The data from the observations, questionnaires and interviews shows that the material give positive influence to the students. The product of material is effective in teaching especially in speaking. It is similar with the result of study in the scope of developing English material for Islamic Education Student (Fitriyah, 2018). The study concludes that the material is effective since real-world tasking and the attractiveness of the product of material enables students to produce more target language in order they to develop their communicative skills. 
on developing material for Business English stated that need analysis is the important factor stage. Based on the need analysis, it is found that the material with Task-Based Language Teaching (TBLT) characteristics is the one that appropriate with students. The experts considered the material good and the students also excited with it. In business English especially in English for banking, there is also a study in developing material for the students (Masrudin, 2018). The result recommend three units of material with task-based approach and communicative approach. Unfortunately, there is no clear conclusion about the effectiveness of the material.

Developing materials for speaking has been the concern of Masruram (2019). It is said that Developing communication skills may give scope to the talented students to express their ideas to the world. Access to spoken English enables to transform our ideas, views, opinions, thoughts, emotions, to obtain information from others and to solve problems and issues. In the study there are some idea of approach, method and activities as the part of the material. However, there is no clear step in conducting the development process and no description of product in the findings.

The study of developing material in maritime higher education is still limited. It is brief description about the development process; need analysis, material development, expert validation and effectiveness assessment. The product is also clearly described. It is hoped to enrich the study

\section{References}

Aeni, N, et.al (2018). The Students' Needs in Maritime English Class at Ami Aipi Makassar, Indonesia. Journal of Language Teaching and Research, 9(6), 1284-1292.

Ahmmed, et.al (2020). A needs analysis of maritime English language skills for Bangladeshi seafarers to work on-board ships. Marine Policy, 119, 104041.

https://doi.org/10.1016/i.marpol.2020.104041

Aniroh, K (2019) The Challenges of TeacherStudents in Developing ESP Teaching Materials. Asian ESP Journal, 15 (2), 4256

Attan, A, et.al (2016) Exploring Industry Expectation of Graduating Students Oral Communication Ability. Asian ESP Journal, 12 (3), 2539

Bardach, E. A practical guide for policy analysis: the Eightfold path to more effective problem solving (3 rd ed (2009). Washington, DC: CQ Press

Bernaus, M (2008) Teacher Motivation Strategies, Student Perceptions, Student Motivation, and English Achievement. The Modern about material development especially in maritime higher education.

\section{Conclusion}

The product of this research is English material for students at Nautical Department of Politeknik Ilmu Pelayaran Semarang. The result of need analysis showed that there was limited material available and it was not appropriate to teach speaking in the classroom. This condition make students keep silent in the classroom and be passive to the lecturers' questions and instructions. Next, the model of material for students at Nautical department has been developed with communicative approach. The material is produced by following the stages: planning, developing, validating by experts, revising and trying out. There are 3 units produced namely (1) Initial Call (2) Message Marker (3) On Board Communication Phrases. This research is expected to give the contribution to the teaching and learning English at Politeknik Ilmu Pelayaran Semarang especially for students at Nautical Department.

\section{Acknowledgement}

This paper was written for the Research and Community Services Project of Politeknik Ilmu Pelayaran Semarang and fully funded by the institution. Therefore, the author would like to address the gratefulness to the lecturers, students and all parties that support the research writing.

\section{Language Journal 92}

Blakey, T. N. (1987) English for Maritime Studies. London: Prentice Hall International

Borg, W. R \& Gall, M. D, Gall. J. P (1989) Educational Research: An Introduction ( fifth edition). New York: Longman, Inc.

Borg, W. R \& Gall, M. D, Gall. J. P (2003) Educational Research: An Introduction (7th edition). New York: Longman, Inc.

Bruton, Antony. (2005) Process Writing and Communicative-Task-Based

Instruction:Many Common Features, but More Common Limitations? TESL-EJ. Desember 2005 Volume 9, Number 3.

Catherine, Logie. Kutz, W. Anna, Erika \& Nisbeth, Allister. (1997) Marlins. English for Seafarers. Study Pack 1. Glasgow: Marlins

Cheng-jun, Wang. (2006) Designing Communicative Task for English College Course. A Disertation. China: Chongqing Normal University and Yangtse Normal University.

Cohen, L, L. Manion \& K. Morrison. (2007) Research Methods in Education. New 
York: Routledge.

Contia, W. Lai.( 2007). The Influence of Learner Motivation on Developing Autonomous Learning in an English-for-SpecificPurposes Course. A Disertation. University of Hongkong.

Demydenko, N. (2012). Teaching Maritime English: A Linguistic Approach.Journal of Shipping and Ocean Engineering (2). Ukraine

Dirgeyasa, I. W. (2018). The Need Analysis of Maritime English Learning Materials for Nautical Students of Maritime Academy in Indonesia Based on STCW'2010 Curriculum. English Language Teaching, 11 (9), 41-47.

Fitriyah, I (2018) Developing English Material for Islamic Education Students of IAIN Kediri. Jurnal Bahasa Lingua Scientia, 10 (1)

Guest, M (2016) Overcoming Institutional Barriers to Establishing an ESP Programme: A Case Report in Japan. Asian ESP Journal, 12 (3), 724

Grice, Tony. (2009). English for Mariners. Wesfalische Wilhemls Universitas Munster

Hashim, H (2018) Language Learning Strategies Used by Adult Learners of Teaching as A Second Language (TESL). TESOL International Journal, 13 (4), 3948

Hutchinson, Tom \& Waters, Alan. (1987). English for Specific Purposes. Cambridge: CUP

Jarvis, H \& Atsilarat, S. (2010). Shifting paradigms: from a communicative to a context-based approach. Asian EFL Journal

Lamb, M. (2007.) The Impact of School on EFL Learning Motivation: An Indonesian
Case Study. TESOL QUARTERLY Vol. 41, No. 4, December 2007

Marselia. et.al (2017). The Implementation of Standard Training, Certification and Watchkeeping 2010 to Redesign The Maritime English Syllabus for Fulfilling Students' Needs. English Education Journal. 7 (2).

Masruddin (2018). Designing Appropriate English Learning Materials for Syariah Economy and Syariah Banking Study Program Students at IAIN Palopo. Asian ESP Journal, vol 14 (4), 42-46

Masuramm, J. et. Al (2019) Developing Speaking Skills through Task-based Materials. Procedia Computer Science 172 (2020) 60-65

Suyitno, I (2019) Designing Indonesian Learning Materials for Communication Purposes for Foreign Learner (2019). Asian ESP Journal, Vol 18, No 10

Tomlison, Brian. (1998) Materials Development in Language Teaching. Cambridge: CUP

Trenkner, P., (2009). Profiling the Maritime English Instructor, 4th IAMU General Assembly Kobe, Jpan

Yahya, A, et.al (2019) Developing Appropriate English Learning Material for Syariah Economy Law Study Program at IAIN Palopo Indonesia. Asian ESP Journal, 15 (1.2), 2233

2009. IMO. Model Course 3.17. Maritime English. IMO. Rev.09. London: International Maritime Organization 2002. IMO. Standard Marine Communication Phrases. London: International Maritime Organization 